\title{
A Paleogene trans-Antarctic distribution for Ripogonum (Ripogonaceae: Liliales)?
}

\author{
Raymond J. Carpenter, Peter Wilf, John G. Conran, and N. Rubén Cúneo
}

\begin{abstract}
An impressive and growing list of biogeographically interesting plant and animal taxa occur in Paleogene sediments of both southern Australia and southern South America, indicating trans-Antarctic distributions during the warm past. Here, we provide the first evidence that the living, woody, Australasian monocot Ripogonum was present during the early Eocene of Patagonia, Argentina. Two fossil leaves are sufficiently well preserved in overall shape, size, and fine venation details to be assigned to the genus, being closely comparable to leaves of the extant species $R$. album and $R$. scandens and the recently described early Eocene species $R$. tasmanicum from Tasmania, Australia. The new species, R. americanum, is described. Overall, this evidence suggests that Ripogonum had a significantly larger past range, including Antarctica, during the early Paleogene, when Antarctica was much more closely connected to both Tasmania and South America and high latitude climates were warm and wet. Ecologically, the South American Ripogonum was probably a scrambling vine in mesic forest and grew in association with a rich understory flora of ferns and angiosperms.
\end{abstract}

Raymond J. Carpenter. School of Earth and Environmental Sciences, Benham BIdg DX 650312 , University of Adelaide, South Australia 5005, Australia and School of Plant Science, University of Tasmania, Private Bag 55, Hobart, Tasmania 7001, Australia.

Peter Wilf. Department of Geosciences, Pennsylvania State University, University Park, Pennsylvania 16802, United States of America.

John G. Conran. Australian Centre for Evolutionary Biology and Biodiversity, School of Earth and Environmental Sciences, Benham Bldg DX 650 312, University of Adelaide, South Australia 5005, Australia.

N. Rubén Cúneo. Museo Paleontológico Egidio Feruglio, Consejo Nacional de Investigaciones Científicas y Técnicas, Trelew 9100, Chubut, Argentina.

Keywords: Argentina; Australasia; Eocene; Liliales; new species; Ripogonum

PE Article Number: 17.3.39A

Copyright: Palaeontological Association October 2014

Submission: 8 February 2014. Acceptance: 29 September 2014

Carpenter, Raymond J., Wilf, Peter, Conran, John G., and Cúneo, N. Rubén. 2014. A Paleogene trans-Antarctic distribution for Ripogonum (Ripogonaceae: Liliales)? Palaeontologia Electronica Vol. 17, Issue 3;39A; 9p;

palaeo-electronica.org/content/2014/921-early-eocene-ripogonum 


\section{INTRODUCTION}

Interest in Southern Hemisphere biogeography has accelerated in recent years, in large part because of the discovery of new fossils and the increased use of molecular data to estimate the timing of lineage diversifications. During the early Paleogene, Antarctica was largely ice-free, and there were no significant water gaps between this continent and Australia and South America (Lawver et al., 2011). Moreover, early Eocene climates at high latitudes were warm and wet enough to support complex vegetation types (Francis et al., 2008; Carpenter et al., 2012; Pross et al., 2012; Contreras et al., 2013). The Antarctic region during this interval can thus be seen as a portal for biotic interchange over vast distances, and the legacy of this past can still be seen in the distributions of numerous modern taxa, famously including Nothofagus (Veblen et al., 1996).

Some plant taxa provide striking direct evidence for trans-Antarctic paleodistributions because they have Paleogene fossil records in both Australia and southern South America, even though they may be extinct in one or both modern regions, or more circumstantially because they have a fossil record in just one area but survive in the other (Hill and Carpenter, 1991). Knowledge of the living Australasian taxa that are present as fossils in South America but extinct there now, in particular, has dramatically increased in recent years, and a large number of these contributions have come from the early Eocene (ca. 52.2 Ma) Laguna del Hunco caldera-lake beds of Chubut, Patagonia, Argentina (see Wilf et al., 2013 for a review). These elements of the Laguna del Hunco fossil assemblage are accordingly considered to represent the western reaches of a vast, trans-Antarctic paleorainforest flora (Wilf et al., 2013). This flora not only included large tree species, but also a range of understory species, notably including several genera of tree and ground ferns (Carvalho et al., 2013) and probable small-statured Laurales trees (Knight and Wilf, 2013).

One small lineage of the monocot order Liliales that shows a classic extant Gondwanan distribution is Ripogonaceae + Philesiaceae. This clade is supported by numerous multigene analyses (Patterson and Givnish, 2002; Davis et al., 2004; Janssen and Bremer, 2004; Givnish et al., 2005; Fay et al., 2006; Kim et al., 2013; Petersen et al., 2013). The species of both families occupy mostly wet forests, where they occur as woody understory shrubs or vines. The Australasian Ripogonaceae comprise only six extant species of Ripogonum in eastern mainland Australia, New Zealand, and Papua New Guinea (Conran and Clifford, 1986), and the Philesiaceae consists only of the Chilean national flower, Lapageria rosea, and Philesia magellanica, which both are species of the moist temperate Valdivian rainforest (Conran and Clifford, 1998; Chileflora, 2012).

Recently, Conran et al. (2009) described Ripogonum tasmanicum from the early Eocene of Tasmania. These authors also noted that the potential for fossilization of Ripogonum leaves was good because the living leaves are robust, abundantly produced, and deciduous at senescence. Indeed, Ripogonum fossils are often locally abundant in New Zealand. These records are mostly Miocene (Holden, 1983; Pole, 1993, 1996, 2007b; Lee et al., 2012), but a recent Eocene discovery has been made (Conran et al., 2013). Here, we provide evidence that Ripogonum was also present in Patagonia, Argentina, during the early Eocene.

\section{MATERIALS AND METHODS}

The two fossils presented here were recovered 29 November and 8 December, 2002, from a single quarry (quarry LH13 of Wilf et al., 2003) of the Laguna del Hunco caldera-lake deposit, Chubut Province, Argentina, which has been described and discussed by numerous authors (e.g., Berry, 1925; Aragón and Mazzoni, 1997; Wilf et al., 2003, 2005, 2013; Zamaloa et al., 2006; Hermsen et al., 2012). The $170 \mathrm{~m}$ stratigraphic section at Laguna del Hunco has 27 fossil plant localities distributed vertically and laterally, concentrated in a densely fossiliferous interval of ca. $60 \mathrm{~m}$ thickness; there are two paleomagnetic reversals and three dated tuffs within the section (Wilf et al., 2003). One of these tuffs, within the fossiliferous interval, was further subjected to multiple ${ }^{40} \mathrm{Ar}-{ }^{39} \mathrm{Ar}$ analyses of sanidines, yielding an age of $52.22 \pm$ $0.22 \mathrm{Ma}$ (early Eocene, Ypresian; M. Smith in Wilf et al., 2005 and Wilf, 2012), which is the working age for the entire floral assemblage. Laguna del Hunco preserved vertebrates and insects as well as more than 200 species of land plants, most of them angiosperms (Wilf et al., 2005, 2009). Since 1999, ca. 6000 fossil plant specimens from Laguna del Hunco have been recovered by expeditions from Museo Paleontólogico Egidio Feruglio (MEF, Trelew, Chubut), where they are curated (repository acronym MPEF-Pb).

Among these large collections at MEF are two compression specimens of the informal leaf morphotype TY171 (Wilf et al., 2005), which is characterised by having a single primary vein with 
divergent secondary vein pairs (marginal and laminal), with the laminal pair suprabasal. These specimens were photographed with a Nikon (Tokyo, Japan) D700 digital SLR camera, and the images were adjusted to optimise brightness and contrast using Adobe Photoshop Elements ${ }^{\circledR}$ software. The leaf surfaces of both fossils were closely examined under epifluorescence, but no useful cuticular features were preserved. Nevertheless, the excellent preservation of the leaf architecture showed compellingly clear similarities to living Ripogonum. Also, considering the rarity of these fossils (only two specimens among thousands, from more than a decade of field work in a remote location) and their unusual geographic interest, we felt it important to present the specimens as is.

An image of a leaf from a herbarium specimen of Ripogonum held at the Queensland Herbarium (BRI) was captured using a Nikon (Tokyo, Japan) D5000 SLR camera. Venation patterns were also observed in some leaves from University of Adelaide collections by X-ray photography of dried leaves, following the method of Christophel and Hyland (1993). Leaf architectural descriptions are adapted from Ellis et al. (2009).

\section{SYSTEMATIC PALAEONTOLOGY}

\author{
Order: LILIALES \\ Family: RIPOGONACEAE \\ Genus: RIPOGONUM \\ RIPOGONUM AMERICANUM R.J. Carp, Wilf, \\ Conran and Cúneo
}

Figures 1.1, 2

Specific Etymology. Named for the first record of Ripogonum in the Americas.

Holotype. MPEF-Pb 6438a,b (part and counterpart; Figures 1.1, 2.1).

Paratype. MPEF-Pb 6439 (Figure 2.2).

Type locality and age. Laguna del Hunco, Tufolitas Laguna del Hunco, early Eocene, Chubut Province, Argentina, quarry LH13 of Wilf et al. (2003).

\section{DESCRIPTION}

Leaves incomplete, holotype preserved portion $91 \mathrm{~mm}$ long (originally perhaps $\sim 105 \mathrm{~mm}$ long), $36 \mathrm{~mm}$ wide (Figures 1.1, 2.1), paratype preserved portion $84 \mathrm{~mm}$ long, $38 \mathrm{~mm}$ wide (Figure 2.2). Lamina symmetrical, ovate to elliptical; base obtuse; apex and petiole unknown, margin entire. Venation: primary venation appearing basal acrodromous due to robust laminal secondaries; primary vein straight, conspicuous, stout, weakening apically; major secondary vein pair suprabasal, arising from the primary vein $\sim 4 \mathrm{~mm}$ from the leaf base at $\sim 30^{\circ}$, decurrent; submarginal vein pair emerging from the leaf base at $\sim 60^{\circ}$; all secondary veins weakening apically, the basal pair forming part of a series of exmedial loops formed by percurrent tertiary veins that connect with the suprabasal secondaries most obviously from the top of the basal third of the leaf to the apex. Tertiary veins between primary and suprabasal secondaries opposite percurrent to random reticulate. Marginal ultimate veins looped.

\section{Comments}

Conover (1983) and Conran et al. (2009) discussed leaf architecture and venation in Ripogonum and for taxa with similar leaves. The latter concluded that the presence of divergent secondary vein pairs (marginal and laminal) with the laminal pair suprabasal (Figure 1.2) is typical only of Ripogonum species. Related and superficially similar net-veined monocots of Smilacaceae and Lapageria generally possess basally divergent secondaries, although some Smilax species can show slightly suprabasal inner vein pairs. Furthermore, Lapageria has very poorly defined brochidodromous loops between the secondary vein pairs and a finely tuberculate midrib and leaf margins. In contrast, the leaves of Philesia are much smaller and show quite different venation (Conover, 1983).

Among dicots there are some Lauraceae that show suprabasal secondary veins, notably Cryptocarya species that are very similar to other Laguna del Hunco leaf fossils, but these always diminish markedly in the apical half to third of the leaf to form loops (see Christophel and Rowett, 1996). In contrast, the major veins of the fossils extend toward the leaf apex. Also, if a marginal pair of veins is present in similar Lauraceae leaves, these veins are much weaker than the suprabasal pair and tend to be very close to the leaf margin. Moreover, Lauraceae species differ markedly from Ripogonum in tending to have strongly and regularly percurrent tertiary veins.

Among extant Ripogonum species, the fossils conform both to some specimens of $R$. album (Figure 1.2) from eastern Australia and New Guinea and $R$. scandens from New Zealand. The likeness between fossil and extant specimens extends to details of fine venation, including the presence of ultimate vein loops. Indeed, we contend that a modern leaf with the same details as preserved in the fossils would readily be accepted as belonging to either of these two extant species. Leaves of the 

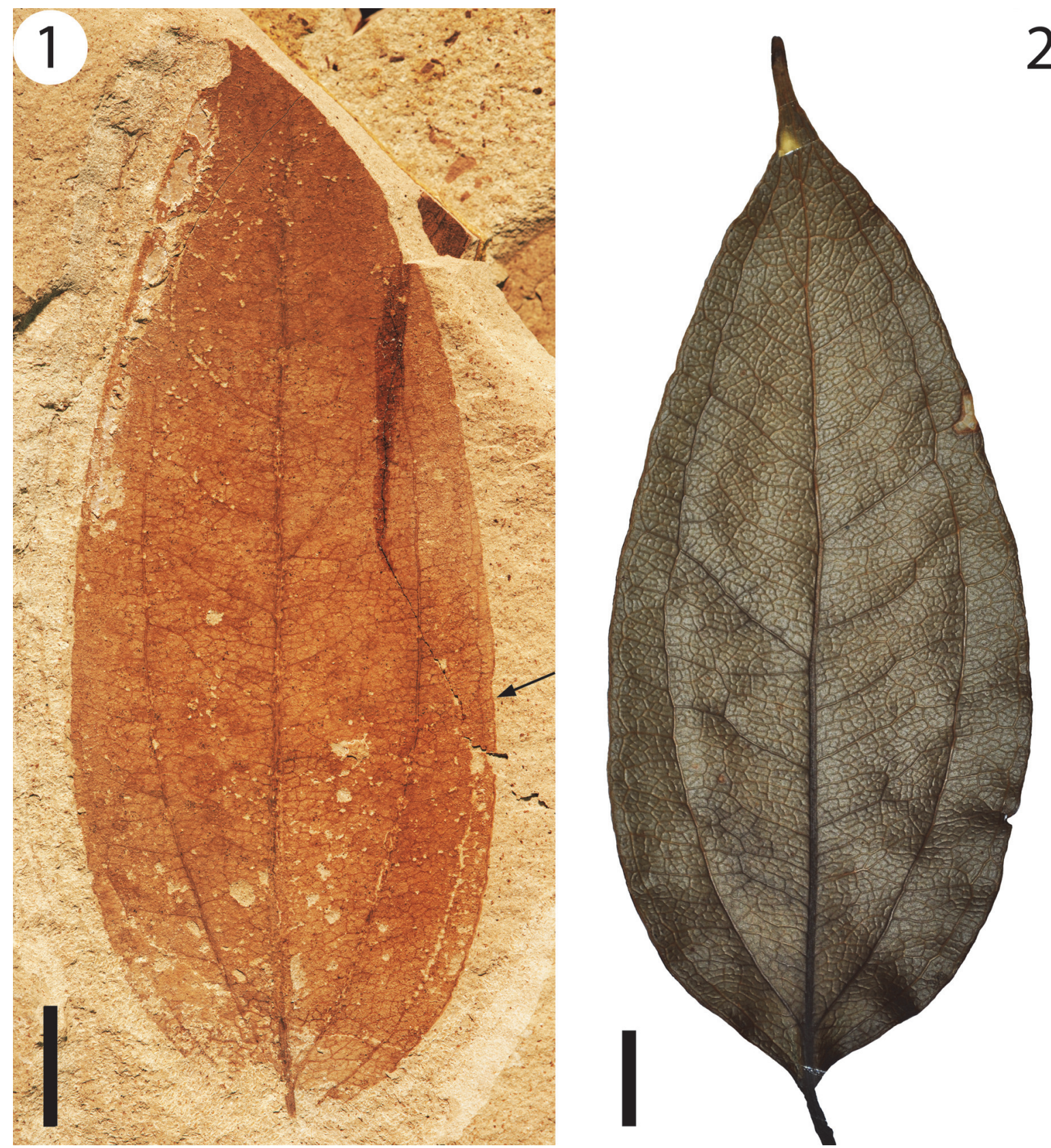

FIGURE 1. Ripogonum americanum sp. nov. from Laguna del Hunco and extant $R$. album, 1, holotype MPEF-Pb 6438a. Note that although the petiolar region is not preserved, a decurrent pair of suprabasal secondary veins and basal pair of submarginal veins are clearly visible. Note also the tertiary veins, higher order reticulate venation, vein loops between the secondary vein pairs, and looped ultimate veins at the margins (arrowed); 2, BRI specimen AQ845060 from Queensland, Australia. Note virtually identical details to those visible in the fossils (Figures 1.1, 2). Scale bars equal $10 \mathrm{~mm}$.

other extant species and of other specimens of $R$. album differ in more obvious ways, as discussed by Conran et al. (2009). The elliptic shape and venation pattern of the fossils exclude the cordatebased species $(R$. elseyanum and $R$. fawcettianum) as close relatives, and the basally divergent submarginal secondaries of the fossils differ from those of $R$. discolor and other specimens of $R$. album (see Conran et al., 2009, figure 5A, D), which run very close to the leaf margins. Ripogonum brevifolium leaves are much smaller, and the suprabasal secondary-vein divergence angle in 

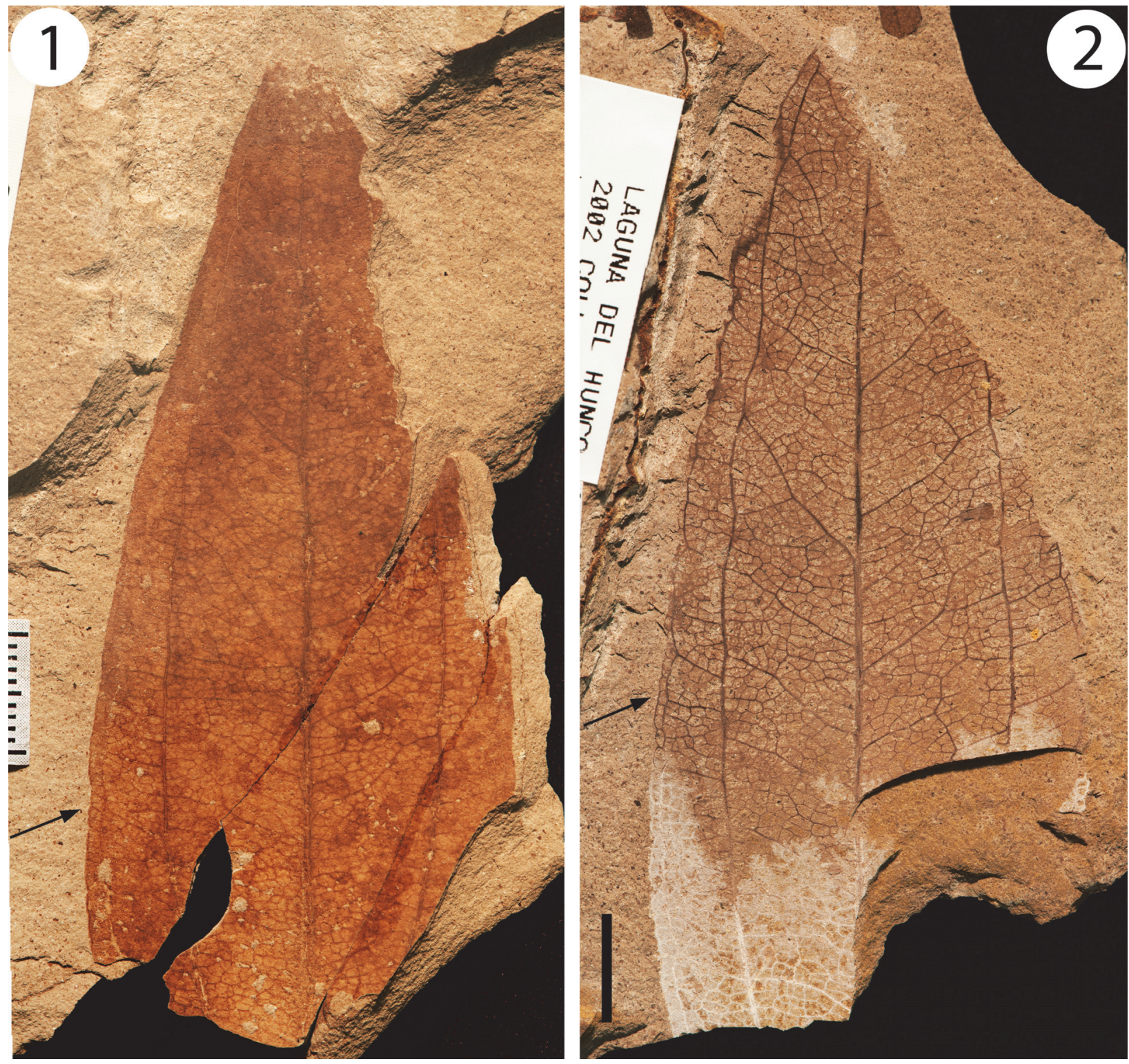

FIGURE 2. Ripogonum americanum sp. nov. from Laguna del Hunco, 1, holotype MPEF-Pb 6438b; 2, paratype MPEF-Pb 6439. Note details as described for Figure 1.1. Examples of clearly preserved looped ultimate veins near the leaf margins are arrowed. Scale bars equal $10 \mathrm{~mm}$.

this species is too narrow to resemble that of the fossils.

In overall size and type of secondary venation, the fossils could not only be included in Ripogonum album and $R$. scandens but also in the early Eocene Tasmanian species $R$. tasmanicum (Conran et al., 2009). However, at both the Tasmanian and Laguna del Hunco sites, specimens are extremely rare. Moreover, although foliar and other character differences might be expected given the vast geographical separation of these sites, the Tasmanian specimens lack higher order venation preservation and the Patagonian specimens lack cuticular preservation, making detailed comparisons impossible. Ripogonum americanum is therefore erected both as the first American record of the genus, and also to recognise the vast temporal and geographical gap between Laguna del Hunco and present-day Australasia.

\section{DISCUSSION}

Ripogonum leaf fossils are now known from the early Eocene of both Patagonia and Tasmania (Pole, 2007a; Conran et al., 2009) and have 


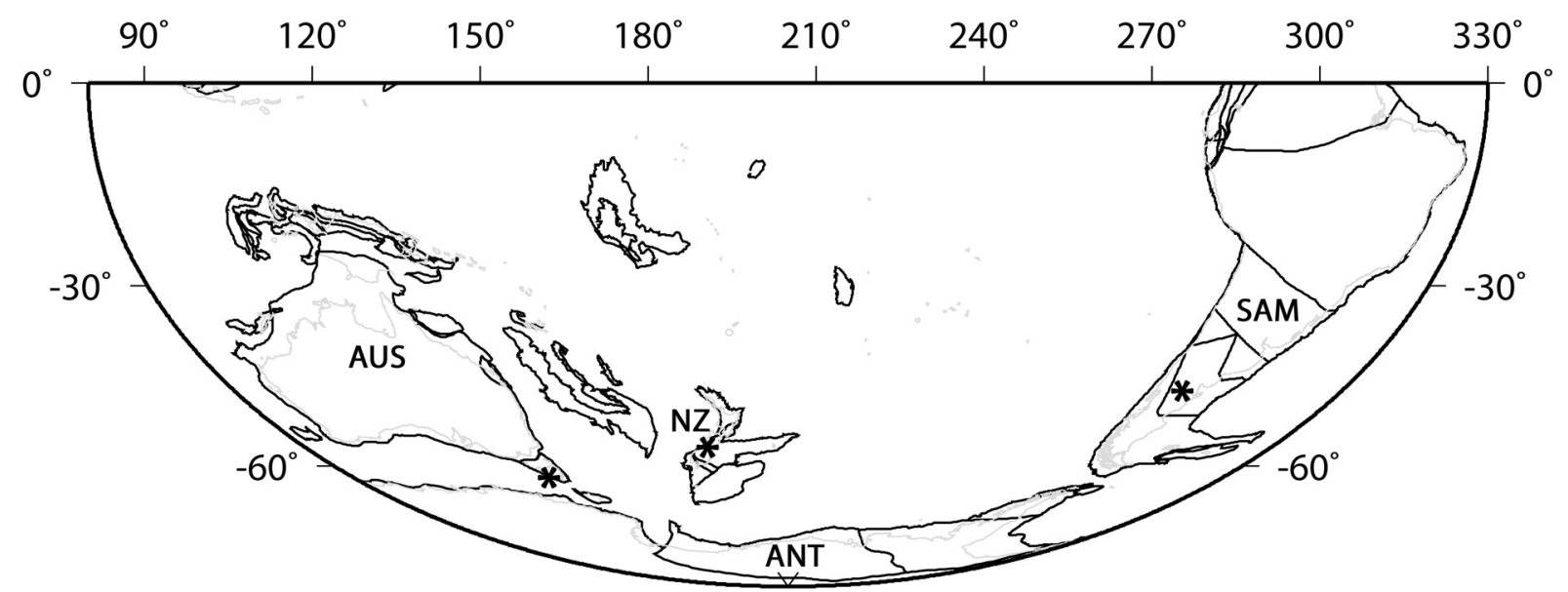

FIGURE 3. Geographic configuration (Mollweide projection) at 52 Ma showing early Eocene records $\left(^{*}\right)$ of Ripogonum. AUS = Australia, NZ = New Zealand, ANT = Antarctica, SAM = South America. Reconstruction made using the ODSN Plate Reconstruction Service (www.odsn.de/odsn/services/paleomap/paleomap.html).

recently been discovered in early Eocene (57-53 $\mathrm{Ma}$ ) sediments from New Zealand (Conran et al., 2013; E.M. Kennedy, personal commun., 2013). These occurrences (Figure 3 ) provide tangible evidence that Ripogonum dates to at least the early Eocene, and they support phylogenetic studies that suggest that Ripogonaceae represents one of many examples in Liliales of ancient Gondwanan connections. The current distributions of Ripogonum in Australasia and Philesiaceae in South America were proposed to be the result of vicariance because the estimated date for the split between these taxa based on molecular evidence was $47 \pm 8.4$ m.y.a. (Vinnersten and Bremer, 2001), or even older (76 m.y.a.; Janssen and Bremer, 2004), and large-scale Antarctic ice formation, deep-water seaways (between Antarctica and both Tasmania and South America) and the Circum-Antarctic current were not all well-developed until the end of the Eocene or later (Lawver et al., 2011, in press). In particular, the Early Eocene Climatic Optimum ( 52-50 Ma) (Zachos et al., 2008), the approximate age of both the Tasmanian (Conran et al., 2009; Carpenter et al., 2012) and Laguna del Hunco Ripogonum specimens, was a period when complex and diverse vegetation types (including mangrove communities) occurred at extremely high southern latitudes (Carpenter et al., 2012; Pross et al., 2012; Contreras et al., 2013).

Conran et al. (2009) also proposed that the position of the Tasmanian Ripogonum tasmanicum fossils in their cladistic analysis of Ripogonum and allies indicated that the deep branches of the phylogeny are at least of Eocene age. Thus, the dis- junction in Ripogonum between Australia and New Zealand could date from when these regions may last have been connected in the Paleogene (Ladiges and Cantrill, 2007). Nevertheless, the small black or red berries of Ripogonum are likely to be attractive to, and readily ingested by, a range of frugivores, and thus the dispersal of seeds over considerable distances has probably been ongoing over millions of years. Further clarification of relationships within the genus will therefore be of interest (Conran et al., 2009).

Ripogonum species are typically stoutlystemmed, prickly vines or shrubs of rainforests (Conran and Clifford, 1986) and probably occupied similar habitats millions of years ago. Ripogonum americanum apparently shared a wet forest home in southern South America with its sister taxa in Philesiaceae, but the fact that $R$. americanum is only represented by two specimens among several thousand collected from Laguna del Hunco suggests that the source plants were uncommon and/ or low-growing. These plants grew with a range of other mesic-adapted lineages including certain ferns (Carvalho et al., 2013), the conifers Papuacedrus (Cupressaceae; Wilf et al., 2009), Dacrycarpus (Podocarpaceae; Wilf, 2012) and Agathis (Araucariaceae; Wilf et al., 2014), and the "dicotyledonous" angiosperms Akania (Akaniaceae; Romero and Hickey, 1976; Gandolfo et al., 1988), Gymnostoma (Casuarinaceae; Zamaloa et al., 2006), Eucalyptus (Myrtaceae; Gandolfo et al., 2011; Hermsen et al., 2012), and certain Atherospermataceae and Monimiaceae (Knight and Wilf, 2013). Like Ripogonum, many of the genera repre- 
sented at Laguna del Hunco became extinct in South America, but they persist in mostly wet forest habitats of Australasia.

\section{ACKNOWLEDGMENTS}

We thank BRI for access to Ripogonum specimens and P. Puerta, K. Johnson, L. Reiner, E. Ruigomez, L. Canessa, B. Cariglino, M. Gandolfo, and C. González for laboratory and field assistance. This research was supported by NSF DEB0919071 and ARC Discovery Project DP110104926. Finally, we would also like to express our thanks to the whole team at PE for undertaking the meticulous editing work, not only for our paper, but also for the whole journal.

\section{REFERENCES}

Aragón, E. and Mazzoni, M.M. 1997. Geología y estratigrafía del complejo volcánico piroclástico del Río Chubut medio (Eoceno), Chubut, Argentina. Revista de la Asociación Geológica Argentina, 52:243-256.

Berry, E.W. 1925. A Miocene flora from Patagonia. Johns Hopkins University Studies in Geology, 6:182-252.

Carpenter, R.J., Jordan, G.J., Macphail, M.K., and Hill, R.S. 2012. Near-tropical Early Eocene terrestrial temperatures at the Australo-Antarctic margin, western Tasmania. Geology, 40:267-270.

Carvalho, M.R., Wilf, P., Hermsen, E.J., Gandolfo, M.A., Cúneo, N.R., and Johnson, K.R. 2013. First record of Todea (Osmundaceae) in South America, from the early Eocene paleorainforests of Laguna del Hunco (Patagonia, Argentina). American Journal of Botany, 100:1831-1848.

Chileflora. 2012. www.chileflora.com (accessed August, 2013).

Christophel, D.C. and Hyland, B. 1993. Leaf Atlas of Australian Tropical Rainforest Trees. CSIRO, Canberra, Australia.

Christophel, D.C. and Rowett, A.I. 1996. Leaf and Cuticle Atlas of Australian Leafy Lauraceae. Flora of Australia supplementary series 6 . Australian Biological Resources Study, Canberra, Australia.

Conover, M.V. 1983. Epidermal patterns of the reticulateveined Liliiflorae and their parallel-veined allies. Botanical Journal of the Linnean Society, 107:295312.

Conran, J.G. and Clifford, H.T. 1986. Smilacaceae, p. 180-196. In George, A.S. (ed.), Flora of Australia. Australian Government Publishing Service, Canberra, Australia.

Conran, J.G. and Clifford, H.T. 1998. Philesiaceae, p. 409-411. In Kubitzki, K. (ed.), The Families and Genera of Vascular Plants. Vol. 3. Flowering Plants. Monocotyledons: Lilianae (except Orchidaceae). Springer Verlag, Berlin, Germany.
Conran, J.G., Bannister, J.M., and Lee, D.E. 2013. An update of monocot macrofossil data, with emphasis on Oceania and the Southern Hemisphere, p. 29-30. In Monocots V Editorial Committee (eds.), 'Monocots V: $5^{\text {th }}$ International Conference on Comparative Biology of Monocots, 7-13 Jul 2013, Fordham University and New York Botanical Garden.' Monocots V Editorial Committee, New York, USA.

Conran, J.G., Carpenter, R.J., and Jordan, G.J. 2009. Early Eocene Ripogonum (Liliales: Ripogonaceae) leaf macrofossils from southern Australia. Australian Systematic Botany, 22:219-228.

Contreras, L., Pross, J., Bijl, P.K., Koutsodendris, A., Raine, J.I., van de Schootbrugge, B., and Brinkhuis, H. 2013. Early to middle Eocene vegetation dynamics at the Wilkes Land Margin (Antarctica). Review of Palaeobotany and Palynology, 197:119-142

Davis, J.I., Stevenson, D.W., Petersen, G., Seberg, O., Campbell, L.M., Freudenstein, J.V., Goldman, D.H., Hardy, C.R., Michelangeli, F.A., Simmons, M.P., Specht, C.D., Vergara-Silva, F., and Gandolfo, M. 2004. A phylogeny of the monocots, as inferred from $r b c L$ and atp $A$ sequence variation, and a comparison of methods for calculating jackknife and bootstrap values. Systematic Botany, 29:467-510.

Ellis, B., Daly, D.C., Hickey, L.J., Johnson, K.R., Mitchell. J.D., Wilf, P., and Wing, S.L. 2009. Manual of Leaf Srchitecture. Cornell University Press, New York.

Fay, M.F., Chase, M.W., Rønsted, N., Devey, D.S., PilIon, Y., Pires, J.C., Petersen, G., Seberg, O., and Davis, J.I. 2006. Phylogenetics of Liliales: summarized evidence from combined analyses of five plastid and one mitochondrial loci. Aliso, 22:559-565.

Francis, J.E., Marenssi, S., Levy, R., Hambrey, M., Thorn, V.C., Mohr, B., Brinkhuis, H., Warnaar, J., Zachos, J., Bohaty, S., and De Conto, R. 2008. From Greenhouse to Icehouse - The Eocene/Oligocene in Antarctica, p. 309-368. In Florindo, F. and Siegert, M. (eds.), Developments in Earth \& Environmental Sciences, volume 8: Antarctic Climate Evolution. Elsevier, Amsterdam, The Netherlands.

Gandolfo, M.A., Dibbern, M.C., and Romero, E.J. 1988. Akania patagonica $\mathrm{n}$. sp. and additional material on Akania americana Romero \& Hickey (Akaniaceae), from Paleocene sediments of Patagonia. Bulletin of the Torrey Botanical Club, 115:83-88.

Gandolfo, M., Hermsen, E.J., Zamaloa, M.C., Nixon, K.C., González, C.C., Wilf, P., Cúneo, N.R., and Johnson, K.R. 2011. Oldest known Eucalyptus macrofossils are from South America. PLOS ONE, 6: e21084.

Givnish, T.J., Pires, J.C., Graham, S.W., McPherson, M.A., Prince, L.M., Patterson, T.B., Rai, H.S., Roalson, E.H., Evans, T.M., Hahn, W.J., Millam, K.C., Meerow, A.W., Molvray, M., Kores, P.J, O'Brien, H.E., Hall, J.C., Kress, W.J., and Sytsma, K.J. 2005. 
Repeated evolution of net venation and fleshy fruits among monocots in shaded habitats confirms a priori predictions: evidence from an $n d h F$ phylogeny. Proceedings of the Royal Society B, 272:1481-1490.

Hermsen, E.J., Gandolfo, M.A., and Zamaloa, M.C. 2012. The fossil record of Eucalyptus in Patagonia. American Journal of Botany, 99:1356-1374.

Hill, R.S. and Carpenter, R.J. 1991. Extensive past distributions for major Gondwanic floral elements: macrofossil evidence. Papers and Proceedings of the Royal Society of Tasmania, 125:239-247.

Holden, A.M. 1983. Studies in New Zealand Oligocene and Miocene plant macrofossils. Unpublished PhD Thesis, Victoria University, Wellington, New Zealand.

Janssen, T. and Bremer, B. 2004. The age of major monocot groups inferred from $800+r b c L$ sequences. Botanical Journal of the Linnean Society, 146:385398.

Kim, J.S., Hong, J.-K., Chase, M.W., Fay, M.F., and Kim, J.-H. 2013. Familial relationships of the monocot order Liliales based on a molecular phylogenetic analysis using four plastid loci: matK, rbcL, atpB and atpF-H. Botanical Journal of the Linnean Society, 172:5-21.

Knight, C.M. and Wilf, P. 2013. Rare leaf fossils of Monimiaceae and Atherospermataceae (Laurales) from Eocene Patagonian rainforests and their biogeographic significance. Palaeontologia Electronica, 16.3.26A: 39pp, 16.56MB;

palaeo-electronica.org/content/2013/546-eocenelaurales-from-patagonia.html

Ladiges, P.Y. and Cantrill, D. 2007. New Caledonia-Australian connections: biogeographic patterns and geology. Australian Systematic Botany, 20:383-389.

Lawver, L.A., Dalziel, I.W.D., and Gahagan, L.M. in press. Intercontinental migration routes for South American land mammals: paleogeographic constraints. In Rosenberger, A.I. and Tejedor, M. (eds.), Origins and Evolution of Cenozoic South American Mammals. Springer, Berlin, Germany.

Lawver, L.A., Gahagan, L.M., and Dalziel, I.W.D. 2011. A different look at gateways: Drake Passage and Australia/Antarctica, p. 5-33. In Anderson, J.B. and Wellner, J.S. (eds.). Tectonic, Climatic, and Cryospheric Evolution of the Antarctic Peninsula. AGU, Washington, D.C., USA.

Lee, D.E., Conran, J.G., Lindqvist, J.K., Bannister, J.M., and Mildenhall, D.C. 2012. New Zealand Eocene, Oligocene and Miocene macrofossil and pollen records and modern plant distributions in the Southern Hemisphere. Botanical Review, 78:235-260.

Patterson, T.B. and Givnish, T.J. 2002. Phylogeny, concerted convergence, and phylogenetic niche conservatism in the core Liliales: insights from rbcL and ndhF sequence data. Evolution, 56:233-252.

Petersen, G., Seberg, O., and Davis, J.I. 2013. Phylogeny of the Liliales (Monocotyledons) with special emphasis on data partition congruence and RNA editing. Cladistics, 29:274-295.
Pole, M. 1993. Early Miocene flora of the Manuherikia Group, New Zealand. 5. Smilacaceae, Polygonaceae, Elaeocarpaceae. Journal of the Royal Society of New Zealand, 23:289-302.

Pole, M. 1996. Plant macrofossils from the Foulden Hills Diatomite (Miocene), Central Otago, New Zealand. Journal of the Royal Society of New Zealand, 26:139.

Pole, M. 2007a. Early Eocene dispersed cuticles and mangrove to rainforest vegetation at Strahan-Regatta Point, Tasmania. Palaeontologia Electronica, 10.3.16A: 66p, 6.93MB; 21p. palaeo-electronica.org/2007_3/126/index.html

Pole, M. 2007b. Monocot macrofossils from the Miocene of southern New Zealand. Palaeontologia Electronica, 10.3.15A: 21p, 2.04MB; palaeo-electronica.org/2007_3/125/index.html

Pross, J., Contreras, L., Bijl, P.K., Greenwood, D.R., Bohaty, S.M., Schouten, S., Bendle, J.A., Röhl, U., Tauxe, L., Raine, J.I., Huck, C.E., van de Flierdt, T., Jamieson, S.S.R., Stickley, C.E., van de Schootbrugge, B., Escutia, C., Brinkhuis, H., and Integrated Ocean Drilling Program Expedition 318 Scientists. 2012. Persistent near-tropical warmth on the Antarctic continent during the early Eocene epoch. Nature, 488:73-77.

Romero, E.J. and Hickey, L.J. 1976. A fossil leaf of Akaniaceae from Paleocene beds in Argentina. Bulletin of the Torrey Botanical Club, 103:126-131.

Veblen, T.T., Hill, R.S., and Read, J., eds. 1996. The Ecology and Biogeography of Nothofagus Forests. Yale University Press, New Haven, USA.

Vinnersten, A. and Bremer, B. 2001. Age and biogeography of major clades in Liliales. American Journal of Botany, 88:1695-1703.

Wilf, P. 2012. Rainforest conifers of Eocene Patagonia: attached cones and foliage of the extant Southeast Asian and Australasian genus Dacrycarpus (Podocarpaceae). American Journal of Botany, 99:562584.

Wilf, P., Cúneo, N.R., Escapa, I.H., Pol, D., and Woodburne, M.O. 2013. Splendid and seldom isolated: the paleobiogeography of Patagonia. Annual Review of Earth and Planetary Sciences, 41:561-603.

Wilf, P., Cúneo, N.R., Johnson, K.R., Hicks, J.F., Wing, S.L., and Obradovich, J.D. 2003. High plant diversity in Eocene South America: evidence from Patagonia. Science, 300:122-125.

Wilf, P., Escapa, I.H., Cúneo, N.R., Kooyman, R.M., Johnson, K.R., and Iglesias, A. 2014. First South American Agathis (Araucariaceae), Eocene of Patagonia. American Journal of Botany, 101:156-179.

Wilf, P., Johnson, K.R., Cúneo, N.R., Smith, M.E., Singer, B.S., and Gandolfo, M.A. 2005. Eocene plant diversity at Laguna del Hunco and Río Pichileufú, Patagonia, Argentina. American Naturalist, 165:634650. 
Wilf, P., Little, S.A., Iglesias, A., Zamaloa, M.C., Gandolfo, M.A., Cúneo, N.R., and Johnson, K.R. 2009. Papuacedrus (Cupressaceae) in Eocene Patagonia, a new fossil link to Australasian rainforests. American Journal of Botany, 96:2031-2047.

Zachos, J.C., Dickens, G.R., and Zeebe, R.E. 2008. An early Cenozoic perspective on greenhouse warming and carbon-cycle dynamics. Nature, 451:279-283.
Zamaloa, M.C., Gandolfo, M.A., González, C.C., Romero, E.J., Cúneo, N.R., and Wilf, P. 2006. Casuarinaceae from the Eocene of Patagonia, Argentina. International Journal of Plant Sciences, 167:12791289. 